\title{
REGION, RELIGION AND POLITICS PRESENTED ON RADIO BY PROFESSOR MAN- DICA MANJA KOVAČEVIĆ, PH.D.
}

\author{
Authors: \\ Draženko Tomić (Ph.D.) \\ University of Zagreb (Croatia) \\ Vladimir Legac (Ph.D.) \\ University of Zagreb (Croatia) \\ E-mail address of the first author: \\ drazenko.tomic@ufzg.hr
}

Lectors:

Blaženka Filipan-Žingić (Ph.D.)

University of Zagreb (Croatia)

Đuro Blažeka (Prof., Ph.D.)

University of Zagreb (Croatia)

... and two other anonymous reviewers

Tomic, D. \& Legac, V. (2020). Region, religion and politics presented on radio by professor Mandica Manja Kovačević, Ph.D. Különleges Bánásmód, 6. (3). 111-119. DOI 10.18458/KB.2020.3.111

\begin{abstract}
Doctor Mandica Manja Kovačević (1929-2011) was a professor at several Croatian teacher training colleges (Čakovec, Kutina and Gospić) and the author of three books and some 60 papers in various journals. She moderated a weekly ten-minute programme for the local radio station in Gospić in the first decade of the 21st century. Thus, more than 300 radio contributions were produced, of which seventy were published in the book "Life on the Highest Wave" (Gospić, 2010). By researching and presenting phonographic recordings not included in the aforementioned book, this paper focused on the topics dealing with the affairs from the Croatian society in the first decade of the 21 century serving as an original sample by means of which Professor Kovačević had presented her personal views and attitudes resulting from life experience and local and traditional expectations. Professor Kovečević's original reviews have attracted the attention of a large number of listeners because they have been able to find answers to questions that are usually contemplated by a contemporary man torn apart between existential challenges and spiritual search.
\end{abstract}

Keywords: Mandica Manja Kovačević, 21st century politics, region, religion

Discipline: pedagogy

\footnotetext{
Absztrakt

VIDÉK, VALLÁS ÉS POLITIKA PROFESSOR MANDICA MANJA KOVAČEVIĆ RÁDIÓMÜSORAIBAN

Mandica Manja Kovačević (1929-2011) több horvátországi tanárképző főiskola professzora volt (Čakovec, Kutina and Gospić), emellett három könyv szerzője, és mintegy 60 tanulmánya jelent meg különböző folyóiratokban. A 21. század első évtizedében moderátora volt egy hetente sugárzott músornak a gospići helyi rádióban, amelynek következtében, több mint 300 műsort készített, s ezek egy részéből
} 
(70 műsor) könyvet jelentetett meg „Life on the Highest Wace” (Gospić, 2010) címmel. A tanulmány célja, hogy górcső alá vonja azokat a hangfelvételeket, amelyek a könyvben nem kerültek feldolgozásra, s kifejezetten azok a témák kerülnek elemzésre, amelyek az évezred elejének horvát társadalmával foglalkoznak. A hangfelvételek elemzése során kiindulópontnak tekintjük Mandica Manja Kovačević által közvetített nézeteket és attitűdöket, ugyanis a professzor asszony szemlélete széles körű figyelmet keltett, hiszen a hallgatók választ kaptak olyan kérdésekre, mint az egzisztenciális és spirituális kutatás szétválasztása.

Kulcsszavak: Mandica Manja Kovačević, 21. századi politika, vidék, vallás

Diszciplína: pedagógia

Dr. Mandica Manja Frković - Kovačević, Ph.D. was born in Gospić in 1929. She belonged to a lineage that was very prominent during WWII, so the post-war period of her life was marked by this very fact (Bežen, Pražić 2016).In Gospić she attended primary school and secondary school (gymnasium). She finished her secondary school education in 1949. She graduated from the Faculty of Humanities and Social Sciences in Zagreb in 1954 with a degree in Croatian language. She received her $\mathrm{Ph} . \mathrm{D}$. degree in theory of literature at the same institution in 1980. After her graduation in 1954 she briefly worked in the town of Gospić in a high school, then in Kutina for another year. Then she returned to Gospić and taught in the local gymnasium and at the Extension for Part-Time Studies in Gospić of the Higher Pedagogical School in Zagreb.In 1962 she moved to the town of Čakovec to teach at the Pedagogical Academy there. A year later she became principal lecturer at the Pedagogical Academy in Gospić where she taught several courses in different study courses (Bežen, 2010).

She published over 60 papers in scientific and professional journals and two books: Treatment of Landscape in a Literary Work(1974) and Literary Methodical Points of View (2001). Dr. Kovačević's bibliography consists of 87 different works, of which about sixty are in scientific and professional journals, as well as two books: Obradapejzaža u književnomdjelu (Landscape Processing in Literary Works) (1974) and Književnometodičkamotrišta (Literary and Methodological Point of View) (2001). She was given several awards: the Likanal Award Plaque in 1976, was the winner of the Ivan Filipović State Award in 1982, she was given the national Order of Danica Medal with the Likeness of Antun Radića, the Public Recognition of LikeSenj County in 1998, Recognition of the Town of Gospić in 2000, Recogniton of the University of Rijeka for the Special Contribution at the Teacher Training College in Gospić in 2003.In addition, Professor Kovačević was distinguished for her excellent human qualities (Tomić, 2016).

Almost on a weekly basis, Professor Kovačević prepared ten-minute contributions for a 10-minute radio programme on the county radio station in Gospić from autumn 2004 until her death. Thus, more than 400 articles with ethical, religious, spiritual, educational, ecological and other topics were produced. The author herself selected 71 papers for the book Life on the Highest Wave (Gospić, 2010). By researching and presenting phonographic recordings not included in the aforementioned book, this paper will focus on the topics dealing with the affairs from the Croatian society in the first decade of the 21 century serving as an original 
sample by means of which Professor Kovačević presented her personal views and attitudes resulting from life experience and local and traditional expectations. For the purpose of this article, its authors analyzed other radio appearances not covered by the aforementioned book, by listening to recordings of the programmes Voice of the Church in Lika from 2007, 2010 and 2011. The authors arbitrarily gave the titles to the articles according to the content, because Prof. Kovačević did not name her radio contributions. (The titles of the contributions in the book mentioned are an addition that was made by the book editor.) The authors of this paper express their deep gratitude to the GospićSenj Diocese for giving them access to their sound recordings library.

\section{Region}

Kovačević looks at the consequences of globalization, which are also reflected in her close social environment. One could sense very clearly in her programmes that she was noticing the increasing number of poor people. Hence the radio programme of March 6th, 2010, calls for solidarity. As language and literature were special fields of her profession, by quoting poems of great poets like e.g. AntunBrankoŠimić's (1898 - 1925) Siromasijeduodpodne do podne (The Poor Eat from Noon to Noon, Kovačević, illustrates all the misery of a man in need, a person who has been heartbroken by the grindstone of the relentless reality, rejected, hungry and disappointed. Kovačević mourns all those who are untouched by the love of their neighbour, but she is also dismayed at the prevailing attitude in the capitalist environment according to which individuals themselves are guilty that banks have taken away everything from them, that their spouse has cheated on them and thrown them out onto the street, that their employer has exploited them, etc.. Although these moods are for the time being prevalent in the business world, they will be transmitted over time into everyday discourse as well as into the discourse of religion: "What have you done wrong that you have been so punished?!" Kovačević calls this system "sinful structures". They produce the poor, on one side the materially poor (the poor) and one the other side spiritually poor (the rich). Hence Kovačević continually through the media expands the values of virtue, gentleness, open-mindedness, mercy as opposed to modern selfishness, hardness, impenitence, ruthlessness, thoughtfulness and utter arrogance (Kovačević, 6th March, 2010).

In seeking the deeper roots of the struggle between the culture of life and the culture of death in the drama of contemporary life, Kovačević, by referring to the words of Pope John Paul II (19782005), diagnosed an eclipse of the meaning of God and man, which is very typical of a global environment where secularism is prevalent. Many have never asked themselves questions about the meaning, whereas others feel that it is not worth bothering with it. Kovačević lists the reasons: some are too grounded, some are not instructed in religion because of various circumstances, others are misdirected under the influence of atheistic ideologies (Marxism, atheism, communism, nihilism, liberalism) or, influenced by the possibilities of positive sciences that cannot prove God by their methods, they say he does not exist. However, the questions of who man is, what he is, where he comes from and where he goes are questions that influence the acceptance of a system of values that indicate the acceptance of a culture of life or a culture of death (Kovačević, 19th August, 2007).

In another programme, Kovačević tells us that modern man are closing in their tower of selfishness, self-sufficiency, ease, unbelief and absence of personality, a solid and dangerous tower of selfworthiness, silence as personal destruction,by referring to Ivan Fuček's words, and continues by noting that the modern man's mentality is eerily horizontal. This horizontalness is rarely penetrated by 
light from the verticalness (Kovačević, 10th April, 2010). Relationships between people have been disturbed, friendship has transformed into egoism, individualism, self-love, the race for wealth, hypocrisy, envy, accusation, media lynching, a decline in morality, a reality in which moral values are disturbed. Opposite them are the realities in which spiritual values are affirmed: justice, love, friendship, promoting dialogue and sharing life with others. Kovačević calls this state of the globalized world Lucifer's effect. In each period, Lucifer has two masks to cheat on two fronts. The first is that he denies spirituality, and the second is that, under the guise of law and democracy, he sells vague freedom without borders in an intimate, business, economic and cultural space. In particular, his effects are striking in politics and protected libertarian journalism. Effective temptation are the incentives of senses that invade virtuous life and habits to destroy families, to impoverish children, and to distance people from each other. They profit from curiosity, vanity, stimuli of the senses, inner black thoughts about possible things. Lucifer knits the net with sweet deals. Kovačević wonders how to combat all this, and she finds the answer in the Decalogue and the Good News (Kovačević, 20th October, 2007).

Another of the new characteristic features of man in this region is the process of depsychization of man, a process in which the soul is sold to the god of the public in return for popularity, for money, or useful friendships; in a word, this means benefits. Kovačević says the truth resides in the public, in statistics and popularity surveys. She refers to Ivica Šola who claims that an individual is not what he is but what is being said about him. That is why it is necessary to publish about oneself as much as possible on a daily basis, including publishing your own privacy to unimaginable details. On the other hand, the truth about a man whose life is marked by loneliness, misunderstanding, neglect and rejection is suppressed or rarely revealed.
These are the two realities of modern societies in transition. (Kovačević, 9th July, 2010.).

In her very last radio appearance on 5th March,2011, just three days before her death, Kovačevicunveiled through the thoughts of another author (Zlatko Miliša) the ideology of moral relativism, which is especially present in media manipulations: the manipulator treats irrelevant issues as essential, abnormal as normal, by twisting the content so that trade could be hidden behind it. (Kovačević,5th March, 2011).

A pretty common topic in her radio programmes is the relationship between the rich and the poor, with particular emphasis on the environment in which they live. By referring to the thought of Šimun Šito Ćorić, Kovačević points to the fact that the rich should be ashamed of being so rich because they probably did not get their possessions in a fair way and especially because they did not use their possessions for the common good. In the lives of such people who have created the world for themselves, however, there are hatred, strife, discord, doubt, despair, darkness and sorrow. As Kovačević seeks to prompt every person so that he can contribute at least a little to finding the magic paths to the poor, to contribute to the construction of a civilization in which no other world should be imagined but to build this existing one. Since all people are engraved in the palm of God, Kovačević wants love and solidarity for all (Kovačević, 19. 6. 2010.).

Another problem that Kovačević faces is the environmental crisis. In the re-evaluation of spiritual values, tradition, knowledge and action, nature, the environment loses its subjectivity. It is exposed to destruction, enslavement, destruction, pollution, and thus transformation. Green oases disappear because of the attacks of the colonizers of nature, garbage and waste dumps are expanding, forests are being destroyed, rivers and lakes are being polluted, medicinal plants are being plundered, bio crime is spreading, etc. The destruction of nature 
destroys man, since he becomes a factor in the destruction and exploitation of natural wealth (Kovačević, 2010). Kovačević is committed to the restoration of nature, and cooperation with nature, an ecological conscience that will oppose the ideology of economic expansion, catastrophic value judgment, consumer culture and wastefulness of society, air pollution, production of massive amounts of waste and more. The highlighted problems require a change in social relationships. Referring to MarijanBiškup, Kovačević argues that the cause of the ecological crisis is a lack of sense of responsibility and a lack of conscience on the part of a man who looks only at himself. Then comes ignorance: man made life easier for himself by developing the technique, but he did not follow what technical civilization brings along. There is also egoism where one does not think of the well-being of the other, the greed for profit and the thirst for power that otherwise cause economic and social problems. Kovačević points to a moral vision of the world starting from the source. It means that she points to the creator. She concludes that whenever man is not at peace with God, the earth is then also not at peace with his Creator (Kovačević, 5. 6. 2010.).

The question arises: where is man? Who is man, his identity and what is the meaning of life? In his prose poem The Song about Burevjesnik, Maksim Gorki wrote "Man, sounds dignified". Of course, he referred to positive values of man. In order to be dignified, man has to have a criterion of reasoning. This criterion is not a theoretical one, but a criterion of awareness, a criterion of the heart, a criterion of love for the brother of man. For a modern man, everything becomes questionable. What to do and why to do something? Drawn into the spiritual emptiness, modern man is often satisfied with his choice and style of behaviour, where there is no need for reasoning and no need for recognition of good and evil. There is, in fact, the knot of everything, the question of all questions and the answer to all the answers. (Kovačević, 2010).
Today's post-modern world, that is, the current society, will one day also become an old society on the scale of historical development. Some archaeologists will in the distant future excavate and discover the old world, that is, today's postmodern world, the world that left behind glass structures, robots, chips, and the world that destroyed much of nature for some material interests. And, they may wonder and astound. But even though the appearance of civilization becomes more refined over time, man in his essence remains always the same, primitive or modern, one who loves or hates, builds or destroys (Kovačević, 2010).

\section{Religion}

Religion is one of the aspects of life. By means of religion the secret of death and the world are revealed. Through religion, it is possible to experience the almighty being that man perceives in his depths, unconsciously or subconsciously encounters with him. For Kovačević, the true religion is that which reconciles man with God from whom he has broken away. It touches the deepest human reality, and it holds the greatest dignity. The believer knows that faith is not based on obviousness or on the possibility of strictly rational explanations, in giving correct answers, but on trust. Although in the New Testament faith is referred to as the acceptance of the word of God incarnated in Christ, it is as such a personal pursuit of communion with God. Kovačević says that many contemporaries do not see it, and even throw it away. Some people justify that it does not make sense, someone else that God cannot prove himself by the scientific method, andthere are those that have never asked themselves a religious question, and let alone the ultimate question: Is there a God? She finds that the interlocutor often lacks answers to questions about faith and God or waves their hand and moves on to other topics. Why? When asked who you are when you do not believe in God, it is diffi- 
cult to tell him that he is just a perishable substance (Kovačević, 28th July 2007).

Kovačević (by analysing Frano Prcela's thoughts) finds that in the society of greed, leisurely living and the like described above, the profession of faith has become formalistic religiosity. The individual relies on rituals and customs, and receiving the sacraments is merely a formality. This collective religiosity lives without a personal image of God and lacks the depth of faith (Kovačević, 30th May, 2010). Despite this condition, Kovačević accepts the existence of religion. She summarizes the reason for this in the thought of Pope Benedict XVI: Morality lives enrolled in a broader religious horizon and outside that environment is lifeless and formal. (Kovačević, 26th February, 2011). It has its last foundation in the authority that is higher than man, the authority that can morally oblige him, and that is only the God the Creator (Kovačević, 5th February, 2011.).

When referring to religion, Kovačević inevitably mentions a religious institution, in her case it is most often the Catholic Church. It was not uncommon for her to refer specifically to the speeches of Pope Benedict XVI (2005-2013). It was during his pontificate that she made her radio contributions. And she joined the then-frequent media commentaries on the pope's speeches, especially in late 2006 and early 2007. Thus, on 27th January, 2007, Kovačević used Benedict's alleged statement about atheists as a means of hell and his evil to ask who the atheists really were. With the minutiae of scholars, she, on the basis of several dictionaries, interprets the etymology of the word atheist pointing to two types of atheism, the practical one, that is, the atheism of those who live as if there was no God, and the theoretical one, that is, the atheism of those who prove the impossibility of God's existence. Kovačević proves to be contemporary here, and in the continuation of her study she refers to an article in the Jutarnji List (from 5th and 6th January, 2007) and observations from that article that the pope's calling of an atheist heralds the return of medieval thinking, that the pope indirectly criticizes science and that he should be sued for causing mental pain with the threat of hellish torment. In this context, Kovačević also quotes statements of some, as she put it, „orthodox critics of the pope, church and religion", like MiroslavRadman, Ivica Krizmanić, Pavlić and Boris Dežulović. In her discussion of their statements she says that: " that it can be $\langle\ldots\rangle$ concluded that they are filled with hatred and with intention to start a decisive fight against religion, the Church and the Pope in a wonderful, dissolute, libertarian world. It would have been more fair if the author of a challenging article had also cited the opinions of scholars who have different views and provided readers with the opportunity to make their own judgment about the statements of others." In the continuation of the same radio programme, Kovačević also cites the opinions of some theistic scientists, mostly natural scientists, who confirm that there is no science without faith, adding that these are the opinions of $"<\ldots>$ those that have been thrown into the basket by sovereign thinkers, atheist scientists. This throwing has been done without any parliamentarism, which should be expected at their intellectual level". And she concludes with these words: "Therefore the goal in this radio programme was to reasonably approximate the difference of opinion in the encounter of science and religion. The occasion was a challenging article, Science in the Dungeon of the Pope's Statements" (Kovačević, 27th January, 2007). On some other occasions, Kovačević also refers to atheism. Thus, on 25th August, 2007, she comments on some excerpts from the book The God Delusion by Richard Dawkins. Here, too, she cited the opinions of opposing teaching authors. They argue that natural selection, therefore the whim of mechanical necessities of matter in motion, is not the mechanism by which the world is created. Kovačević prefers to lean on the opinion that recognizes God's plan in 
nature and the pinnacle of creation in man (Kovačević, 25th August 2007; 20th January, 2007).

\section{Politics}

Systems of contemporary values in society are prescribed by governments, parties, associations, media professionals, foreign advisers. The consequence of this is that in modern society, man lives most often on a pattern that has been imposed by a civilizing trend: consumption, pleasure, fun, power, prominence, tourism, splendour and the life of the "stars." But on the other hand, there are excess incidents: rape, incest, paedophilia, blackmail, money laundering, divorce, wars and more. The proclaimed freedoms are the result of protests of these or those, and many times have nothing to do with common sense. In the eclipse of society, Kovačević does not close her eyes to the multitude of examples of humanitarian action that helps another in need. But even these actions are without question about the meaning, the question of why that particular man had got into such misery. Most often, these are just fire measures, garments that hide the defeat nakedness of modern man. Kovačević points to the split relationship between the individual and society in the field of ethical values. She calls for the integration of spiritual and social action, for the prosperity of human society. It is in this integration that modern man is lagging behind (Kovačević, 14th July 2007).

Kovačević looks at the importance of electronic and other media in the contemporary environment. It is an obvious fact that the media have the greatest influence on public opinion, people's attitudes and their behaviour. The functioning of the modern pluralistic society is essential to the media, which increases the impact and interest in the content they present. She does not question the role of the media and journalists, who should be critical public awareness, or guardians of democracy, they should warn about the mistakes and wrong moves and abuses of the holders of public authority. Even the Black Chronicle is not questionable, as are neither the negatives in films and series, because they are an integral part of life. The amount of these contents and the place given to them is questionable because of the effects that they produce. Negatives are given more space than necessary and they tend to be multiplied, and at the same time not all aspects of these negatives, let alone their causes, have been considered. Thus, Kovačević continues, the aforementioned Black Chronicle enhances the effect of misconduct, and usually goes with other spices, such as milder or more pronounced pornographic content, unreal lifestyles, economic crime, etc. (Kovačević, 2010).

During the 2007 parliamentary elections in Croatia, Kovačević looked at the real moral labels of contemporary society through the Decalogue. They were also discussed in the Croatian Parliament Sabor: Sunday as a non-working day, same-sex marriages, sexual freedom, abortion and similar topics. In her radio address, Kovačević persists in her claim that new winds of vague freedom do not purify society from sellers of cheap fortune. In this context, she also wondered about the message of the local church regarding the 2007 parliamentary elections. The Church should pay attention to the humanistic and spiritual values in the life of the individual and the community, which, she was convinced, should not bother political activists of any orientation (Kovačević, 11th July, 2007).

\section{Conclusion}

By researching and presenting phonographic records that were not included in the afore-mentioned Kovečević's book, the authors of this paper have exposed new topics that dealt with events that were current in Croatian society in the first decade of the 21 st century. They were used by this Croatian scholar from Lika County to present her personal views and attitudes resulting from her life experi- 
ence and from the local and traditional hypotheses. Her writings, as DragutinRosandić put it, open wide thematic fields, broad cognitive fields, and this has been done argumentatively and by means of suggestive expression, which is again based on her own personal experience. (Rosandić, 2010). Hence, Professor Kovečević's original reviews have attracted the attention of a large number of listeners because they have been able to find answers to questions that are usually contemplated by a contemporary man torn apart between existential challenges and spiritual quests.

It becomes prominent that the author insists on the social dimension of society, the existence of the extremely rich and the extremely poor. This is precisely her most obvious signal that something is wrong with the society and man. What is even more horrifying is that such a selfish view of the world becomes a ubiquitous way of thinking. It leads to egoism, self-sufficiency, alienation, and ultimately the meaning of life and existence is lost. It is exactly because he has lost sight of some higher goal of its existence, moreover, the whole environment is such that it obscures man's answer to the question of the meaning. She calls it the Lucifer's effect.

Without any doubt, it can be said that Kovačević believed that people should turn to a system of ethical values, so that through her ten-minute radio addresses she wanted to be the voice of the possibility of a more humane relationship between people and a more humane relationship towards nature. Hence, in contrast to contemporary "inventions", she contrasted spiritual values such as justice, love, friendship, and promotion of dialogue. Both because of the radio programme in which she presented her views and because of her own convictions, Kovačević believed that religion and faith are a significant factor in the implementation of a better world.

\section{References}

Bežen,A. \&Grahovac-Pražić, V.(2016). Dobri duh Gospića. Život $i$ djeloManjeKovačević $i$ njezin rod Frkovića.Gospić - Zagreb: OgranakMaticehrvatske u Gospiću - Stajer-graf.

Bežen, A. (2010). Prof. dr. sc. ManjaKovačevićrođ. Frković (1929.-2011.).Metodika 11, 21, 313-319.

Grahovac-Pražić, V. (2010).Tematiziranje u etičkokršćanskomdiskursu.In M.Kovačević, Životnanajvišemvalu(pp. 172-173) Gospić: Gospićkosenjskabiskupija.

Kovačević, M. (2010). Životnanajvišemvalu. Promišjjanja o etickim, religijskim $i$ drugimtemama, Gospić: Gospićko-senjskabiskupija.

Kovačević, M. (20. 1. 2007.). Ateizam u suvremenomdruštvu-znanost i vjera (only on the radio)

Kovačević, M. (11. 7. 2007.). Parlamentarnizbori, ideologija i Crkva (only on the radio)

Kovačević, M. (14. 7. 2007.). Pojavnostsuvremenecivilizacije (only on the radio)

Kovačević, M. (28. 7. 2007.). Svjetonazor i religija (only on the radio)

Kovačević, M. (19. 8. 2007.). Ideološkisustavi o čovjeku (only on the radio)

Kovačević, M. (25. 8. 2007.). Osvrtnaevolucionizam (only on the radio)

Kovačević, M. (20. 10. 2007.). Luciferovefekt (only on the radio)

Kovačević, M. (6. 3. 2010.). Milostđe (This title is also in the book: Kovačević, Life...)

Kovačević, M. (10. 4. 2010.). Bijelanedjelja (This title is also in the book Kovačević, Life...)

Kovačević, M. (5. 6. 2010.). Čovjek i priroda (only on the radio)

Kovačević, M. (19. 6. 2010.). Sveti Franjo i bogatstvo (only on the radio)

Kovačević, M. (9. 7. 2010.). Štoznačivjerovati? (only on the radio)

Kovačević, M. (5. 2. 2011.). Maranatha (only on the radio)

Kovačević, M. (5. 3. 2011.). Moralnirelativizam (only on the radio) 
KÜLÖNLEGES BÁNÁSMÓD, VI. ÉVF. 2020/3.

Rosandić, D. (2010). Na duhovnimstazama- Tomić, D. (2016)Stara Gospićanka In A. Božjidoziv i ljudskiodzivi In M.Kovačević, Bežen,esV. Grahovac-Pražić. Dobri dub Gospića. Životnanajvišemvalu(pp. 174-179) Gospić: Gos- Život i djeloManjeKovačević i njezin rod Frkovića(pp. pićko-senjskabiskupija. 129-131) 